Науковий вісник НлТУ України Scientific Bulletin of UNFU

https://nv.nltu.edu.ua

https://doi.org/10.36930/40290906

Article received 24.09.2019 p.

Article accepted 26.12.2019 p.

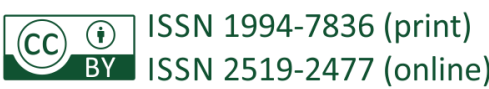

@ Correspondence author

R. D. Stetsyk

biochem.ddpu@gmail.com

UDK 574.3:581.9

С. С. Монастирська, Р. Д. Стецик

Дрогобищький державний педагогічний університет ім. Івана Франка, м. Дрогобич, Україна

\title{
ОСОБЛИВОСТІ ПОШИРЕННЯ РАННЬОВЕСНЯНИХ РОСЛИН У ХВОЙНО- ШИРОКОЛИСТЯНИХ ЛІСАХ ОКОЛИЦЬ СЕЛА ІЛЬНИК ТУРКІВСЬКОГО РАЙОНУ
}

\begin{abstract}
Наведено результати дослідження щодо поширення ранньовесняних рослин, які ростуть на території околиць села Ільник Турківського району. На території дослідження виявлено 14 видів ранньовесняних рослин, які належать до 9 родин. За кількістю видів домінують родини Asteraceae та Ranunculaceae (21,5\% від загальної кількості родин), Amaryllidaceae $(14,4 \%)$; інші родини представлені одним видом і їх частка становить 7,1\%. Усі виявлені на території дослідження ранньовесняні рослини належать до 13 родів. Встановлено, що тільки один рід Anemone має 2 види - A. nemorosa та A. ranunculoides i становить 15,3 \%; інші роди представлені одним видом, відсоткова частка яких становить 7,7 \% на кожний рід. Найпоширенішими на території дослідження є види Anemone nemorosa, Dentaria glandulosa та Scilla bifolia, поодиноко трапляються види Gagea lutea, Galanthus nivalis, Petasites kablikianus та Anemone ranunculoides. Встановлено, що 4 види із флори ранньовесняних рослин Ільника підлягають охороні і занесені до Свропейського Червоного Списку (Primula veris, Scilla bifolia) та Червоної книги України (Leucojum vernum, Galanthus nivalis). Загалом виявлені на території дослідження рослини свідчать про незначне поширення та рясність ранньовесняних рослин.
\end{abstract}

Ключові слова: ранньовесняні рослини; флора; село Ільник; Anemone nemorose.

Вступ. Дослідження біорізноманіття має важливе значення для його збереження, розроблення засобів і методів раціонального природокористування. Встановлення повного видового складу та аналіз флори сприятимуть вирішенню багатьох питань флористики та фітогеографії. Вивчення рослинного світу територій, розроблення наукових питань щодо збереження біотичного різноманіття й відновлення рослинних ресурсів належать до найважливіших питань сучасної ботаніки (Hetman, 2007; Onyshchenko, 2007).

Синузія ранньовесняних рослин $є$ важливою частиною лісових угруповань, що формуються на багатих грунтах. Вони відзначаються порівняно невисокими насіннєвою продуктивністю та дальністю рознесення насіння, потерпають від антропогенного впливу та зміни складу деревних видів у процесі господарського використання лісів. Експедиційні дослідження флори проводять влітку без повторного вивчення іiї весняного аспекту. Тому ранньовесняну флору досліджено значно менше, ніж інші види лісових ценозів, про що свідчить невелика кількість публікацій (Malynovskyi, 1980; Panchenko, Lukash \& Chornous, 2006).

Відомості про генофонд рослин кожного регіону $\epsilon$ невід'ємною ланкою у вирішенні питань селекції, сільського господарства та розвитку національного господарства загалом. Для забезпечення гармонійного роз- витку використання ресурсів важливо з'ясувати поширення та різноманітність конкретних видів у межах держави чи окремого регіону. Характерною особливістю флори досліджуваної території Турківського р-ну є те, що спостерігається різночасовий розвиток рослин. Наприклад, для ранньовесняного періоду розвитку лісу характерна яскрава різноманітність ефемероїдів, тобто багаторічних трав'яних рослин 3 дуже коротким вегетаційним (наземним) періодом, що відбувається у сприятливий для них час 3 достатнім освітленням і закінчується до появи листків на деревах і кущах (Kahalo, 2003; Stoiko, 2006). Такий свосрідний ритм розвитку ранньовесняних рослин $\epsilon$ відображенням давньої еволюції цих рослин.

Вирішення зазначених вище питань актуальне для регіонів з високим рівнем видового багатства та оригінальністю флори. До таких в Українських Карпатах належить Ільницьке лісництво Турківського р-ну. Тому мета цієї наукової роботи - дослідити особливості поширення ранньовесняних рослин на території околиць с. Ільник.

Об'єктом дослідження є ранньовесняні види рослин, які ростуть на території околиць с. Ільник Турківського р-ну.

Предметом дослідження є методи і засоби виявлення особливостей поширення ранньовесняних рослин у хвойно-широколистяних лісах.

\section{Інформація про авторів:}

Монастирська Світлана Семенівна, канд. біол. наук, доцент, завідувач кафедри біології та хімії. Email: svitlana.monastyrska@gmail.com; https://orcid.org/0000-0001-8529-800X

Стецик Розалія Дмитрівна, викладач, кафедра біології та хімії. Email: biochem.ddpu@gmail.com; https://orcid.org/0000-0002-3747-8353

Цитування за ДСтУ: Монастирська С. С., Стецик Р. Д. Особливості поширення ранньовесняних рослин у хвойно-широколистяних лісах околиць села Ільник Турківського району. Науковий вісник НЛтУ України. 2019, т. 29, № 9. С. 38-41.

Citation APA: Monastyrska, S. S., \& Stetsyk, R. D. (2019). Features of early-flowering plants spreading in coniferous-deciduous forests of Ilnyk village in Turka district. Scientific Bulletin of UNFU, 29(9), 38-41. https://doi.org/10.36930/40290906 
Матеріали та методи дослідження. Польові роботи виконували впродовж березня 2017 - початку травня 2018 рр. маршрутним методом. Маршрути охоплювали територію Ільницького лісництва і прокладались так, щоб якнайповніше й об'єктивніше дослідити поширення та рясність ранньовесняних рослин території.

Під час маршруту записували всі рослини, які траплялися в дорозі. При цьому визначали рясність кожного виду рослин, місцезнаходження, екологічні умови росту, проводили опис окремих рослин.

Усі виявлені види рослин цієї території заносили у конспект флори. Для цього рослини комплектували за родами та родинами. Гербарні зразки ідентифікували за визначником вищих рослин України (Prokudin \& Dobrochaev, 1999; The Plant List, 2019). Для визначення рясності рослин користувались шкалою О. Друде (Drude, 2003).

Результати дослідження. Територія села Ільник розташована в горах західної частини Українських Карпат, що мають назву Верхньодністровські Бескиди. Найвищі вершини розміщені на північному сході від початку села і мають такі назви: Шимонець (1131 м н.р.м.), Менчіл Зубрицький (1086 м н.р.м.), Менчіл Радецький (або Плішка - 1034 м), Каменець (988 м) (Laba, 2009).

Ільницьке лісництво Турківського лісового господарства розміщене на території Ільницької та Риківської сільських рад, площею 2084 га, зокрема вкрита лісом площа - 1863,9 га, або 84,2 \%. Рубки формування й оздоровлення лісів проводять на площі 35 га, зі заготівлею 2444 м $^{3}$ деревини. Щорічний об'єм відновлення становить 12-15 га, 10 га - завдяки природному поновленню. Заготівлю насіння проводять в кількості 50 кг. Фонд головного користування становить $4320 \mathrm{~m}^{3}$ (Tyryk, 2000).

Флора досліджуваного регіону досить різноманітна і багата, оскільки є види, які часто трапляються та розсіяні по всій території. На території Ільницького лісниц- тва переважають лісовкриті землі, а найбільші площі цих земель займають хвойні ліси (близько 46 \%). Для Ільницького лісництва характерні хвойно-широколистяні ліси зі смереки звичайної (Picea abies), ялиці білої (Abies alba) та бука лісового (Fagus sylvatica).

Серед хвойних дерев Pinus sylvestris займає площу 0,2 га, Picea abies - 421,9, a Abies alba вкриває 965,3 га земельної ділянки. Серед твердолистяних найпоширенішим є Fagus sylvatica 3 площею 897,4 га, загальний запас деревини якого становить 277,32 тис. м² (Stoiko, 2006).

Підлісок листяного і мішаного лісів утворюють переважно кущі малини (Rubus idaeus), ліщини (Corylus avellana). У підліску також поширені крушина ламка (Frangula alnus), верба гостролиста (Salix acutifolia), калина звичайна (Viburnum opulus), горобина звичайна (Sorbus aucuparia), бузина чорна (Sambucus nigra), ялівець звичайний (Juniperus communis). На галявинах ростуть низенькі кущики брусниці звичайної (Vaccinium vitis-idaea) і чорниці звичайної (Vaccinium myrtillus) (Tyryk, 2000).

Досить поширені також трав'яні рослини, а саме: шавлія залозиста (Salvia glutinosa), розхідник звичайний (Glechoma hederacea), щитник чоловічий (Driopteris filis-mas), орляк звичайний (Pteridium aquilinum), печіночниця звичайна (Hepatica nobilis), медунка червона (Pulmonaria rubra Schott). Найбільше видове різноманіття характерне для родин Айстрові (Asteraceae) та Злакові (Роасеае), представники яких добре пристосовані до різноманітних умов та мають низку прогресивних ознак. Поряд з ними домінують родини Губоцвіті (Lamiaceae), Бобові (Fabaceae), Розові (Rosaceae) (Kahalo, 2003).

Серед значного фіторізноманіття трав'яних рослин важливе місце посідають ранньовесняні рослини. Узагальнивши отримані результати дослідження флори Ільницького лісництва, встановлено основні види ранньовесняних рослин та їх рясність (таблиця).

Таблиця. Систематичний аналіз флори досліджуваного району

\begin{tabular}{|c|c|c|c|}
\hline № 3/ח & Вид & Родина & Рясність \\
\hline 1 & Анемона дібровна (Anemone nemorosa) & Жовтецеві (Ranunculaceae) & Дуже рясно \\
\hline 2 & Зубниця залозиста (Dentaria glandulosa) & Капустяні (Brassicaceae) & Дуже рясно \\
\hline 3 & Проліска дволиста (Scilla bifolia) & Холодкові (Asparagaceae) & Дуже рясно \\
\hline 4 & Первоцвіт весняний (Primula veris) & Первоцвітні (Primulaceae) & Рясно \\
\hline 5 & Мати-й-мачуха (Tussilago farfara) & Айстрові (Asteraceae) & Рясно \\
\hline 6 & Стокротки багаторічні (Bellis perennis) & Айстрові (Asteraceae) & Рясно \\
\hline 7 & Пшінка весняна (Ficaria verna) & Жовтецеві (Ranunculaceae) & Рясно \\
\hline 8 & Жовтяниця черговолиста (Chrysosplenium alternifolium) & Каменеломкові (Saxifragaceae) & Рясно \\
\hline 9 & Медунка лікарська (Pulmonaria officinalis) & Шорстколисті (Boraginaceae) & Рідко \\
\hline 10 & Білоцвіт весняний (Leucojum vernum) & Амарилісові (Amaryllidaceae) & Рідко \\
\hline 11 & Зірочки жовті (Gagea lutea) & Лілійні (Liliaceae) & Поодиноко \\
\hline 12 & Підсніжник звичайний (Galanthus nivalis) & Амарилісові (Amaryllidaceae) & Поодиноко \\
\hline 13 & Кремена судетська (Petasites kablikianus) & Айстрові (Asteraceae) & Поодиноко \\
\hline 14 & Анемона жовтецева (Anemone ranunculoides) & Жовтецеві (Ranunculaceae) & Поодиноко \\
\hline
\end{tabular}

На території дослідження виявлено 14 видів ранньовесняних рослин, які належать до 9 родин. За кількістю видів домінують родини Айстрові (Asteraceae) та Жовтецеві (Ranunculaceae) - по 3 види (або 21,5\% від загальної кількості родин), Амарилісові (Amaryllidaсеае) - 2 види $(14,4 \%)$; інші родини представлені одним видом і становлять $7,1 \%$ (рис. 1).

Усі досліджувані рослини належать до Покритонасінних. Кількість видів класу Однодольні (Liliopsida) -
4, що становить 28,5\%, Дводольні (Magnolisopsida) 10 видів або 71,5\%. Така перевага Покритонасінних, зокрема Дводольних, $\epsilon$ характерною для сучасного етапу флорогенезу (рис. 2).

Усі виявлені на території дослідження ранньовесняні рослини належать до 13 родів. Виявилось, що тільки один рід Anemone має 2 види - A. nemorosa та A. ranunculoides i становить $15,3 \%$; інші роди представлені од- 
ним видом, відсоткова частка яких становить 7,7 \% на кожний рід (рис. 3).

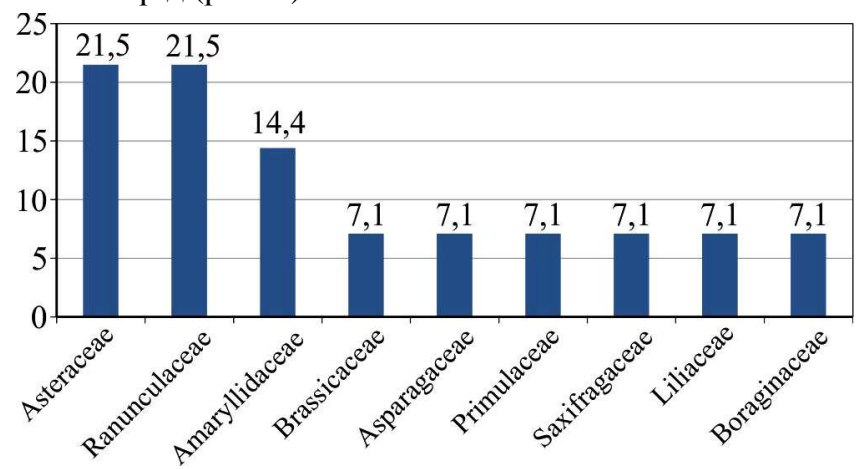

Рис. 1. Родинний спектр ранньовесняних рослин села Ільник

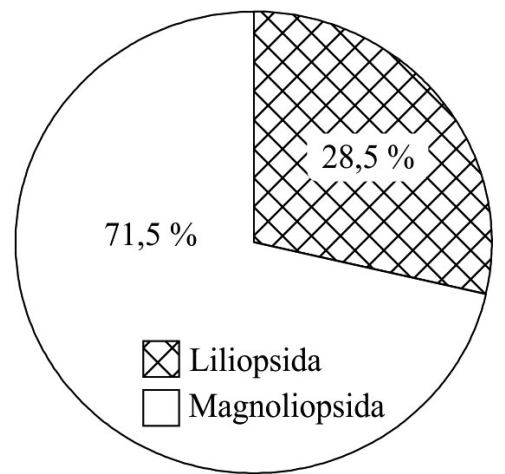

Рис. 2. Відношення кількості Однодольних і Дводольних рослин

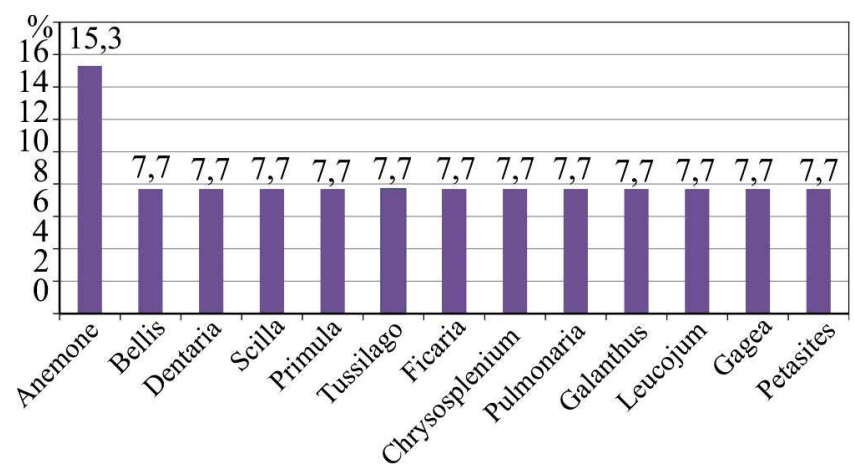

Рис. 3. Характеристика ранньовесняних рослин у родовому спектрі

Обговорення отриманих результатів. Найпоширенішими на території дослідження є види Anemone nетоrosa, Dentaria glandulosa та Scilla bifolia, які належать до родин Ranunculaceae, Brassicaceae та Asparagaceae відповідно. Поодиноко трапляються види Gagea lutea, Galanthus nivalis, Petasites kablikianus та Anemone ranunculoides.

Варто зазначити, що із двох видів роду Анемона (Anemone) поширенішим є вид $A$. nemorosa, рясність якого є великою, натомість A. ranunculoides трапляється поодиноко. Види із родини Asteraceae Tussilago farfara та Bellis perennis поширені рясно, а рясність виду Petasites kablikianus є дуже низькою. 5 видів трапляються рясно. За рясністю досліджувані види можна розподілити так: 5 видів трапляються рясно $(35,7 \%)$, дуже рясно - 3 види $(21,4 \%)$; рідко - 2 види $(14,3 \%)$; поодиноко - 4 види $(28,6 \%)$ (рис. 4$)$.

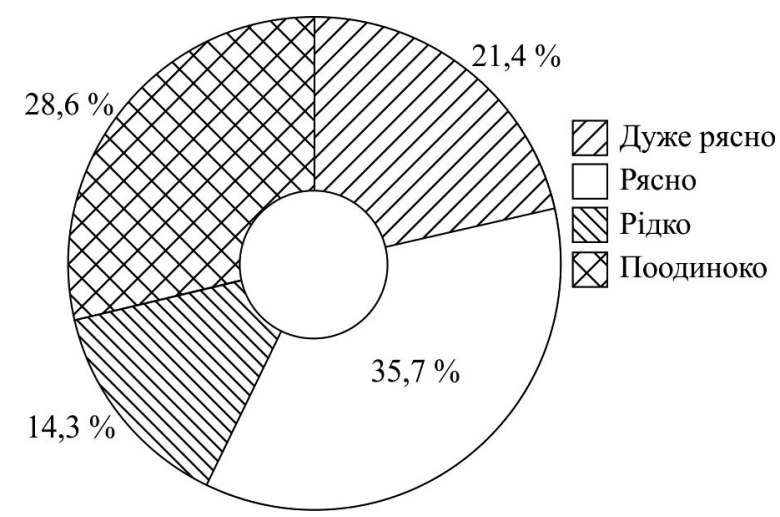

Рис. 4. Рясність ранньовесняних рослин села Ільник

Із описаних ранньовесняних рослин 4 види підлягають охороні, зокрема Primula veris та Scilla bifolia занесено до "Європейського Червоного Списку", категорія "R" - рідкісний вид; Leucojum vernum та Galanthus nivalis занесено до Червоної книги України з природоохоронним статусом - неоцінений (Drude, 2003).

Висновки. Отже, на території дослідження виявлено 14 видів ранньовесняних рослин, які належать до 9 родин. За кількістю видів домінують родини Айстрові (Asteraceae) та Жовтецеві (Ranunculaceae) - по 3 види, Амарилісові (Amaryllidaceae) - 2 види; інші родини представлені одним видом. Ці рослини належать до 13 родів, з яких тільки рід Aneтопе має два види A. nemorosa та $A$. ranunculoides; інші роди представлені одним видом.

Виявлені на території дослідження рослини свідчать про незначне поширення та рясність ранньовесняних рослин, що пов'язано із особливостями їх розвитку та умовами навколишнього середовища. Серед досліджуваних ранньовесняних рослин 4 види $(28,5 \%$ від загальної кількості) підлягають охороні.

\section{References}

Drude, O. (2003). Plants Ecology. Kyiv: Ukropchyk, 208 p. [In Ukrainian].

Hetman, V. I. (2007). Skole Beskids National Nature Park. Ecological Bulletin, 9, 29-44. [In Ukrainian].

Kahalo, O. O. (2003). Flora of the Lviv Region. Native Nature, 8, 4758. [In Ukrainian].

Laba, V. M. (2009). History of the Ilnik village (from ancient times to 1939). Lviv, 188 p. [In Ukrainian].

Malynovskyi, K. A. (1980). Highlands of the Ukrainian Carpathians. Kyiv: Scientific thought, 280 p. [In Ukrainian].

Onyshchenko, V. A. (2007). Patterns of spring ephemeroids spread in deciduous and coniferous-deciduous forests of Ukraine. Ukrainian Botanical Journal, 64(6), 806-824. [In Ukrainian].

Panchenko, S. M., Lukash, O. V., \& Chornous, O. P. (2006). Spring ephemeroids deciduous forests left-bank Polissya. Ukrainian Botanical Journal, 63(5), 671-680. [In Ukrainian].

Prokudin, Yu. N., \& Dobrochaev, D. M. (Eds). (1999). Determinant of higher plants of Ukraine. Kyiv: Fitosotsiotsentr, 548 p. [In Russian].

Stoiko, S. M. (2006). Individual groups and species of forest trees and shrubs of Lviv region, (pp. 98-105). Lviv: Svit. [In Ukrainian].

The Plant List. (2019). Retrieved from: https://www.theplantlist.org/

Tyryk, Ya. M. (2000). Turkivshchyna. Tourist guide. Lviv, 128 p. [In Ukrainian]. 


\section{FEATURES OF EARLY-FLOWERING PLANTS SPREADING IN CONIFEROUS-DECIDUOUS FORESTS OF ILNYK VILLAGE IN TURKA DISTRICT}

Finding ways to restore natural vegetation, preserve rare and typical phytocoenoses, and enhance the protective functions of mountain vegetation requires a comprehensive study of vegetation. The sinusia of early-flowering plants is an important part of the forest communities formed on rich soils, as they are suffering from anthropogenic influence. The early spring plant species growing in the area around the village of Ilnyk of Turka District has been studied. Field study was conducted during March 2017 - early May 2018 using the route method. All identified plant species in this territory were brought into the flora abstract. The study revealed 14 species of early-flowering plants belonging to 9 families. The predominant species are Asteraceae and Ranunculaceae (21.5\% of the total number of families), Amaryllidaceae (14.4\%); other families are represented by one species and constitute $7.1 \%$. All early flowering plants found in the study area belong to 13 genera. Only one genus of Anemone was found to have 2 species, A. nemorosa and $A$. ranunculoides, accounting for $15.3 \%$; other genera are represented by one species, which percentage is $7.7 \%$ for each genus. Species from Asteraceae Tussilago farfara and Bellis perennis are abundant, and the abundance of Petasites kablikianus is very low. 5 species are abundant. The abundance of the studied species can be divided as follows: 5 species occur abundantly ( $35.7 \%$ ), 3 species occur very abundantly $(21.4 \%) ; 2$ species occur rarely $(14.3 \%) ; 4$ species are single species $(28.6 \%)$. The most common species in the study area are Anemone nemorosa, Dentaria glandulosa and Scilla bifolia, species of Gagea lutea, Galanthus nivalis, Petasites kablikianus and Anemone ranunculoides are occurred singly. The plants found in the study area indicate a low prevalence and abundance of early-flowering plants, which is related to their developmental characteristics and environmental conditions. Among the studied early spring plants, 4 species ( $28.5 \%$ of the total) are subject to protection.

Keywords: early-flowering plants; flora; Ilnyk; Anemone nemorosa. 